\title{
Modelling of a turbojet gas turbine engine
}

\section{Document Version}

Accepted author manuscript

Link to publication record in Manchester Research Explorer

\section{Citation for published version (APA):}

Klein, D., \& Abeykoon, C. (2015). Modelling of a turbojet gas turbine engine. In host publication (pp. 198-204)

\section{Published in:}

host publication

\section{Citing this paper}

Please note that where the full-text provided on Manchester Research Explorer is the Author Accepted Manuscript or Proof version this may differ from the final Published version. If citing, it is advised that you check and use the publisher's definitive version.

\section{General rights}

Copyright and moral rights for the publications made accessible in the Research Explorer are retained by the authors and/or other copyright owners and it is a condition of accessing publications that users recognise and abide by the legal requirements associated with these rights.

\section{Takedown policy}

If you believe that this document breaches copyright please refer to the University of Manchester's Takedown Procedures [http://man.ac.uk/04Y6Bo] or contact uml.scholarlycommunications@manchester.ac.uk providing relevant details, so we can investigate your claim.

\section{OPEN ACCESS}




\section{Modelling of a Turbojet Gas Turbine Engine}

\author{
Dominik Klein \\ Division of Applied Science, Computing and Engineering, \\ Glyndwr University, Mold Road, LL11 2AW, Wrexham, \\ United Kingdom \\ E-mail: kleindomi@t-online.de
}

\author{
Chamil Abeykoon \\ Division of Applied Science, Computing and Engineering, \\ Glyndwr University, Mold Road, LL11 2AW, Wrexham, \\ United Kingdom \\ E-mail: c.abeykoon@glyndwr.ac.uk; yabeykoon01@qub.ac.uk
}

\begin{abstract}
Gas turbines are one of the most important internal combustion engines in the modern world's transportation. Any possible improvements of the performance of the gas turbine engines would help to minimize the world's annual fossil fuel consumption and hence the emissions of the adverse greenhouse gases. Therefore, modelling and simulation of gas turbines have been a major focus of many fields in aviation to improve their performance. In this work, it is aimed to model a turbojet gas turbine engine theoretically and computationally. On this basis, the pre-established equations were implemented in MATLAB Simulink to create a model of a turbojet engine. The influence of atmospheric conditions was also taken into account in creating the model. Furthermore, GasTurb was used to study the turbojet engines and provided useful results to explore the engine performance. The theoretical and Simulink models were in a good agreement within reasonable limits which verifies the correctness of the Simulink model established in this paper. Therefore, the proposed model can be used in investigating the performance of various types of turbojet engines without performing time taking theoretical calculations.
\end{abstract}

Keywords-Turbojet engine; Turbine; Compressor; Modelling; Simulation; Engine performance.

\section{INTRODUCTION}

Gas turbines are used in a wide variety of applications in aviation and electricity generation. It is especially important for aviation as these engines can power huge aircrafts and also are cost-efficient in operation. Today, a great attention has been paid on optimizing the fuel consumption and usability of these engines while minimizing their noise level. This serves the purpose of the smallest possible environmental impact of emissions and low consumption of resources. Thermal and materials engineering play a vital role in designing of gas turbines and improving their performance.

Previous work by Jian-hua and Ying-yun [1], MATLAB was used to solve thermodynamic parameters of a microturbojet. On this basis, they used GasTurb to model and simulate a gas turbine engine. The steady performance under off-design conditions and the impact of the external environment on the gas turbine's performance were analysed in detail. The results showed that the effects of ambient temperature changes on gas turbines are quite significant. With the increase of the ambient temperature, the specific fuel consumption continued to rise; thermal efficiency increased gradually while the thrust was decreasing.

\section{A. Basic operation of gas turbines}

A gas turbine is an internal combustion engine. Today most of the modern passenger, cargo and military aircrafts are powered by various size/type of gas turbine engines. A turbine basically consists of five components: intake, compressor, combustion chamber, turbine and propelling nozzle. The principle of operation can be described in terms of simple steps. The air flows through the inlet into the compressor with one or more compression stages where the compressor will deliver a high pressure air flow that required in the turbine inlet. Energy is then added by spraying fuel into the air and igniting it in the combustion chamber. The combustion generates a high temperature flow, which consists of a mixture of combustion gas and air. The high temperature and high pressure gas enters the turbine and expands down to the exhaust pressure. One part of the energy is converted into kinetic energy or rotational energy, which produces a shaft work output in the process. Thereby, the compressor is driven. The other part produces the thrust in the propelling nozzle. Thrust is a mechanical force which is generated through the reaction of accelerating a mass of gas [2], [3]. A schematic diagram of the engine arrangement and the typical temperature-entropy and pressure-volume diagrams of a gas turbine engine are shown in Figure 1.
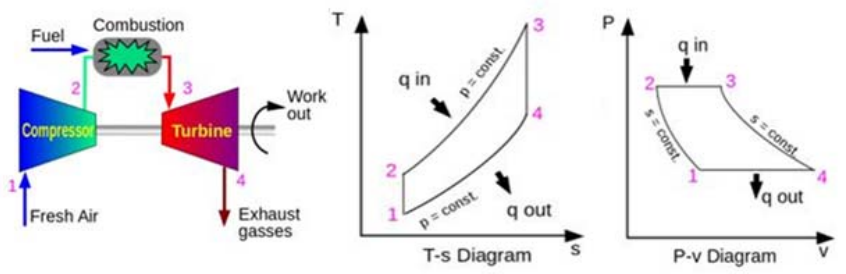

Figure 1: (a): Idealized Brayton cycle for gas turbines, (b): T-s Diagram, (c): P-V Diagram [4]

\section{B. Turbojet}

The first centrifugal-flow turbojet was invented in 1930 by Frank Whittle of the Royal Air Force, and in Germany, Hans von Ohain also patented a similar engine in 1935 [5]. Since then turbojet engines have been widely popular and they are still common in medium range cruise missiles, possibly due to their high exhaust speed, small frontal area, and relative simplicity. A turbojet turbine is designed such that it generates 
the power for driving the compressor and thrust for moving the aircraft. The entire gas flow is conducted through the combustion chamber and the expansion of the exhaust gases in the propelling nozzle to atmospheric pressure to produce a very fast thrust jet. Due to the high exit velocity of the exhaust jet, the turbojet gas turbines are low in efficiency at low speeds. Especially at subsonic speeds (i.e., at low speeds) the specific fuel consumption is high [3]. Because of the fast jet, the turbojet gas turbine produces a high noise level, which limits their usefulness. As per improvements over the time, turbojets have been replaced in slower aircrafts by turboprops which use less fuel. At higher speeds, they have been replaced by turbofans as the propeller is no longer efficient. Basically, the turbofan is quieter and uses less fuel than the turbojet.

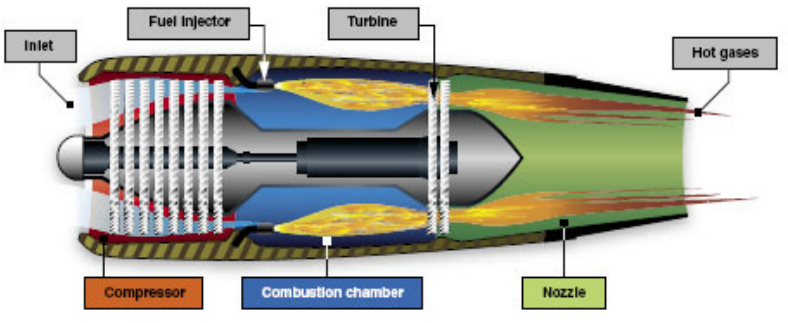

Figure 2: Arrangement of a turbojet gas turbine [6]

\section{Basic Operational Parameters}

The difference between shaft power cycles and aircraft gas turbine cycles is the useful power output. For turbojets the thrust is generated in the propelling nozzle. With gas turbines, higher speeds and greater heights can be achieved and hence the reciprocating engines were replaced by gas turbines. The intake of this type of gas turbines must be considered as a separate component because of its significant effects on the forward speed. The intake has an effect on the engine efficiency and aircraft safety. It is very important to minimize the pressure losses and also to ensure that the air flow enters the compressor with a uniform pressure and velocity. Nonuniform or distorted ambient air flow can cause a surge in compressor which can result in serious mechanical damages due to blade vibrations [7], [8].

The compressor of a gas turbine needs an air flow with an axial Mach number (M) between 0.4-0.5 at its first stage inlet. Subsonic aircrafts will typically cruise between $0.8-0.85$ (M) while supersonic aircrafts operate at speeds from M 2-2.5. The engine operates at maximum power and airflow at take-off with a zero forward speed. The inlet must therefore withstand heavy loads at many operating conditions. Under static operating conditions or at very low forward speeds the intake acts as a nozzle in which the air accelerates from zero velocity $V_{\mathrm{A}}$ to the compressor inlet velocity $V_{1}$. At normal forward speeds the air decelerating form $V_{\mathrm{A}}$ to $V_{1}$ and the static pressure rises from atmospheric pressure $p_{a}$ to the compressor inlet pressure $p_{1}[8]$.

This study is focused on modelling of a turbojet gas turbine and is explored how to develop a gas turbine model on a Simulink platform which comes as close as possible to reality. This will be carried out via theoretical calculations, creating a model in MATLAB-Simulink and also in GasTurb.

\section{ModelLing}

\section{A. Theoretical Modelling}

The steps in developing the theoretical model are discussed below and the parameters considered are given Table I.

TABLE I: THE RELEVANT DATA FOR MODELLING

\begin{tabular}{|c|c|c|}
\hline \multirow{2}{*}{$\begin{array}{c}\text { Parameter } \\
\text { type }\end{array}$} & \multicolumn{2}{|l|}{ Turbojet } \\
\hline & Parameter & Theory - Value \\
\hline \multirow{4}{*}{$\begin{array}{l}\text { Ambient } \\
\text { Parameters }\end{array}$} & Altitude & $10000 \mathrm{~m}$ \\
\hline & Ambient Temperature $\mathrm{T}_{\mathrm{A}}$ & $223.3 \mathrm{~K}$ \\
\hline & Ambient Pressure $\mathrm{P}_{\mathrm{A}}$ & 0.265 bar \\
\hline & Speed of Sound & $299.8 \mathrm{~m} / \mathrm{s}$ \\
\hline \multirow{11}{*}{$\begin{array}{l}\text { Parameters } \\
\text { of the } \\
\text { Gasturbine }\end{array}$} & Speed & $0.8 \mathrm{M}=272 \mathrm{~m} / \mathrm{s}$ \\
\hline & Compressor Pressure Ratio & 8.0 \\
\hline & Turbine Inlet Temperature $T_{3}$ & $1200 \mathrm{~K}$ \\
\hline & Intake Efficieny $\eta_{I}$ & 0.93 \\
\hline & Compressor Efficiency $\eta_{C}$ & 0.87 \\
\hline & Combustion Efficiency $\eta_{B}$ & 0.98 \\
\hline & Turbine Efficiency $\eta_{T}$ & 0.90 \\
\hline & Propelling Nozzle Efficiency $\eta_{N}$ & 0.95 \\
\hline & Mechanical Efficiency $\eta_{M}$ & 0.99 \\
\hline & Combustion Pressure Loss & $4 \%$ \\
\hline & Nozzle Area A & $0.3 \mathrm{~m}^{2}$ \\
\hline \multirow{6}{*}{$\begin{array}{l}\text { Other } \\
\text { Parameters }\end{array}$} & $\begin{array}{l}\text { Specific Heat at Constant } \\
\text { Pressure (Air) } \mathrm{C}_{\mathrm{PA}}\end{array}$ & $1.005 \mathrm{~kJ} /(\mathrm{kg} \cdot \mathrm{K})$ \\
\hline & $\begin{array}{l}\text { Specific Heat at Constant } \\
\text { Pressure (Combustion Gas) } \mathrm{C}_{\mathrm{PG}}\end{array}$ & $1.148 \mathrm{~kJ} /(\mathrm{kg} \cdot \mathrm{K})$ \\
\hline & Specific Heat Ratio of Air $\gamma$ & 1.4 \\
\hline & $\begin{array}{l}\text { Specific Heat Ratio of } \\
\text { Combustion Gases } \gamma_{G}\end{array}$ & 1.333 \\
\hline & Gas Constant R & $287 \mathrm{~J} /(\mathrm{kg} \cdot \mathrm{K})$ \\
\hline & Fuel Calorific Value & $43260 \mathrm{~kJ} / \mathrm{kg}$ \\
\hline
\end{tabular}

Increase in temperature at the air inlet:

$$
\Delta T_{I}=V_{1}^{2} /\left(2 \times C_{P}\right)
$$

For the inlet temperature:

$$
T_{1}=T_{A}+\frac{V_{1}^{2}}{2 \times C_{P}}
$$

$\Delta T_{1}$ is the temperature after isentropic compression to $P_{1} . \Delta T_{1}$ can be related to $T_{1}$ by introducing an isentropic efficiency $\eta_{I}$ defined as:

$$
\frac{P_{1}}{P_{A}}=\left(\frac{\Delta T_{1}}{T_{A}}\right)^{\gamma /(\gamma-1)}
$$

It follows that:

$$
\Delta T_{1}-T_{A}=\eta_{I}+\frac{V_{1}^{2}}{2 \times C_{P}}
$$

So that $\eta_{I}$ can be regarded as the fraction of the inlet dynamic temperature which is made available for isentropic compression in the intake. The intake pressure ratio can then be found from equation (5):

$$
\frac{P_{1}}{P_{A}}=\left(1+\eta_{I} \times \frac{V_{1}^{2}}{2 \times C_{P} \times T_{A}}\right)^{\gamma /(\gamma-1)}
$$


The pressure after intake is given by:

$$
P_{1}=P_{A} \times\left(P_{1} / P_{A}\right)
$$

The pressure at the outlet from the compressor can be found by using the compressor pressure ratio $P_{2} / P_{1}$ :

$$
P_{2}=\left(P_{2} / P_{1}\right) \times P_{1}
$$

The temperature of the work transfers for a given pressure ratio is given by:

$$
T_{2}-T_{1}=\frac{T_{1}}{\eta_{C}} \times\left[\left(\frac{P_{2}}{P_{1}}\right)^{(\gamma-1) / \gamma}-1\right]
$$

Temperature at the compressor outlet:

$$
T_{2}=T_{1}+\frac{T_{1}}{\eta_{C}} \times\left[\left(\frac{P_{2}}{P_{1}}\right)^{(\gamma-) / \gamma}-1\right]
$$

The turbine work is equal to the compressor work divided by the mechanical efficiency of transmission $\left(W_{T}=W_{C} / \eta_{M}\right)$ and hence:

$$
T_{3}-T_{4}=\frac{C_{P A} \times\left(T_{2}-T_{1}\right)}{C_{P G} \times \eta_{M}}
$$

The temperature at the turbine outlet:

$$
T_{4}=T_{3}-\frac{C_{P A} \times\left(T_{2}-T_{1}\right)}{C_{P G} \times \eta_{M}}
$$

The loss of pressure in the combustion chamber can be denoted as $\Delta P_{B}$. Then the pressure at the outlet of the combustion chamber can be defined as:

$$
P_{3}=P_{2} \times\left(1-\frac{\Delta P_{B}}{P_{2}}\right)
$$

The temperature at the turbine outlet with turbine losses:

$$
\Delta T_{4}=T_{3}-\frac{1}{\eta_{T}} \times\left(T_{3}-T_{4}\right)
$$

Then pressure at the turbine outlet can be calculated:

$$
P_{4}=P_{3} \times\left(\frac{\Delta T_{4}}{T_{3}}\right)^{\gamma_{G} /\left(\gamma_{G}-1\right)}
$$

The nozzle pressure ratio can be defined as:

$$
P_{4} / P_{A}
$$

The critical pressure ratio:

$$
\frac{P_{4}}{P_{C}}=\frac{1}{\left[1-\frac{1}{\eta_{N}} \times\left(\frac{\gamma_{G}-1}{\gamma_{G}+1}\right)\right]^{\gamma_{G} /\left(\gamma_{G}-1\right)}}
$$

Since the nozzle pressure ratio $\mathrm{P}_{4} / P_{A}$ is greater than the critical pressure ratio $\mathrm{P}_{4} / P_{C}$ the nozzle is choking. Then, the exit temperature of the for the nozzle outlet $\left(T_{5}\right)$ :

$$
T_{5}=\left(\frac{2}{\gamma_{G}+1}\right) \times T_{4}
$$

and

$$
P_{5}=P_{4} \times\left(\frac{1}{P_{4} / P_{C}}\right)
$$

After the basic calculations, equations for calculating the thrust have been established. Then, the density of the air at the nozzle outlet can be defined as:

$$
\rho_{5}=\frac{P_{C}}{R \times T_{5}}
$$

The velocity of the air at the nozzle outlet:

$$
V_{5}=\left(\gamma_{G} \times R \times T_{5}\right)^{1 / 2}
$$

Then, the specific thrust is given by equation (22):

$$
\begin{aligned}
& \frac{A}{\dot{m}_{5}}=\frac{1}{\rho_{5} \times V_{5}} \\
& F_{S}=\left(V_{5}-V_{1}\right)+\frac{A}{\dot{m}_{5}} \times\left(P_{5}-P_{A}\right)
\end{aligned}
$$

The gross thrust is then:

$$
F_{G}=\dot{m}_{5} \times V_{5}
$$

The ram drag can be defined as:

$$
F_{R}=\dot{m}_{1} \times V_{1}
$$

Then the net thrust can be calculated as follows:

$$
F_{N}=F_{G}-F_{R}
$$

For the air/fuel ratio $\alpha$ :

$$
\alpha=\frac{\text { actual fuel/air ratio }}{\eta_{\mathrm{B}}}
$$

Finally the specific fuel consumption (SFC) can be defined as:

$$
S F C=\frac{\alpha}{F_{S}}
$$

\section{B. Developing the model in MATLAB Simulink}

The steps followed in developing the MATLAB-Simulink model of a turbojet gas turbine engine are presented below.

1) Creating the Model Parameters

First all the individual block diagrams of the components of a turbojet gas turbine (turbine, intake, compressor, burner, turbine and nozzle) were created to obtain the basic structure of the model. To take the atmospheric conditions into account, the component "Atmosphere" was added to the model. For this purpose, the boundary conditions of the respective altitude were entered by following the specifications of the ISA (International Standard Atmosphere) [9].

For implementing the thermodynamic and engine performance parameters, the previously calculated equations were implemented in the corresponding components. This includes units and relationships of the individual equations. For the 
implementation of the full model then input and output variables were set, which are ultimately necessary for the simulation. The relevant data which were used in establishing the simulation and calculation are shown in Table I. The block diagram of the final model obtained in MATLAB-Simulink is shown in Figure 3.

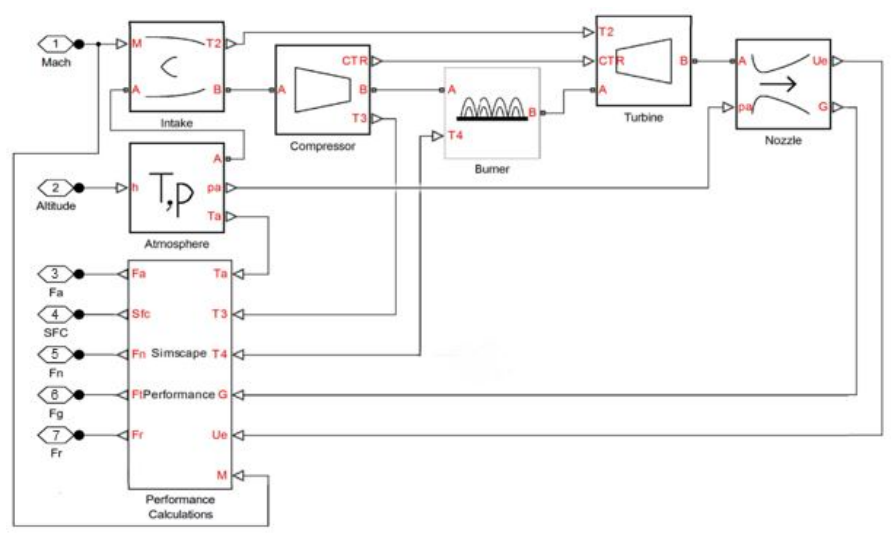

Figure 3: Basic Simulink model of a turbojet gas turbine

All of these blocks include the necessary equations for the calculation of the rquired values which are not visible in Figure 3.

\section{Simulation with GasTurb [10]}

\section{1) Modelling and Simulation with GasTurb}

GasTurb $^{\text {TM }}$ simulates the most important gas turbine configurations used in propulsion or power generation. Virtually all gas turbine performance simulation problems can be solved with GasTurb.

\section{2) Creating the Model Parameters}

GasTurb offers a wide variety of aircraft engine configurations to select from and an arrangement of a turbojet air system in GasTurb is shown in Figure 4.

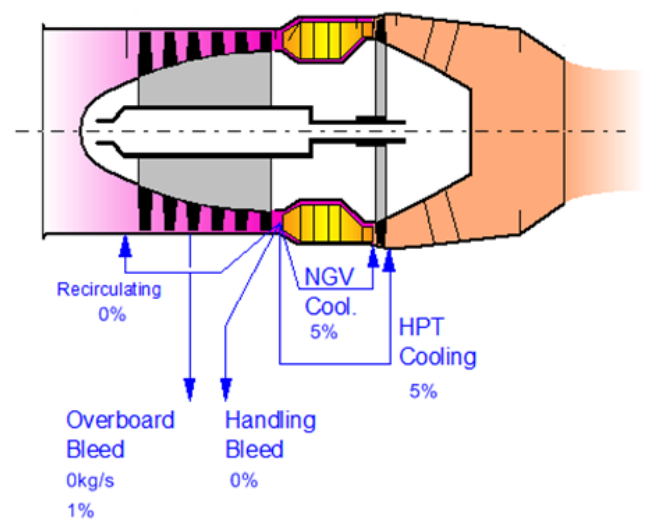

Figure 4: Turbojet Air System in GasTurb [10]

After selecting the proper configuration, the engine parameters presented in Table I were entered into the program. Then, GasTurb calculates the required values for the input parameters as a function of the set altitude and the Mach number.

\section{RESULTS AND DISCUSSION}

At different flight conditions both the thrust and specific fuel consumption will vary, due to the change in the air mass flow with varying density and the variation of momentum drag with the forward speed. Furthermore, even if the engine were run at a fixed rotational speed, the turbine inlet temperature will change with intake conditions. Typical variations of thrust and specific fuel consumption with the change in altitude for a simple turbojet gas turbine are shown in Figures 5 and 6 . In comparison of the values obtained from the calculation, the MATLAB model and GasTurb, it can be seen that the thrust decreases significantly with the altitude due to the favourable effect of lower intake temperature. Specific fuel consumption however shows some improvement with increasing altitude as shown in Table II. Moreover, the specific fuel consumption is dependent upon the ambient temperature. It is obvious from the variation in thrust and specific fuel consumption that the fuel consumption will be greatly reduced at high altitudes.

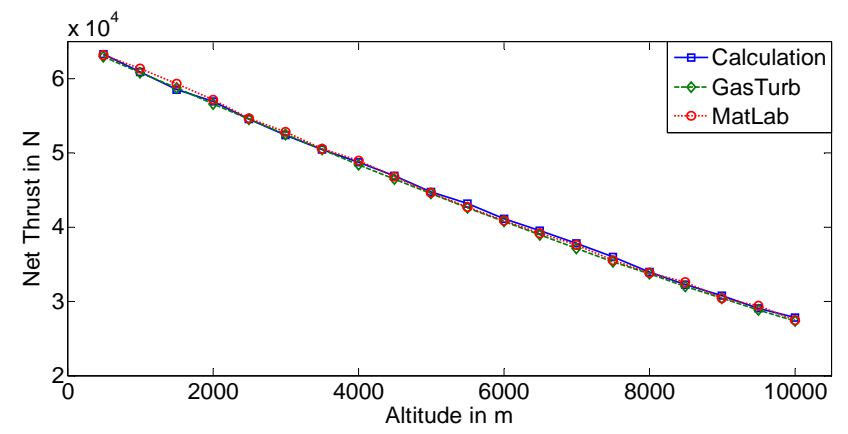

Figure 5: Variation of net thrust with the altitude at a Mach number of 0.8

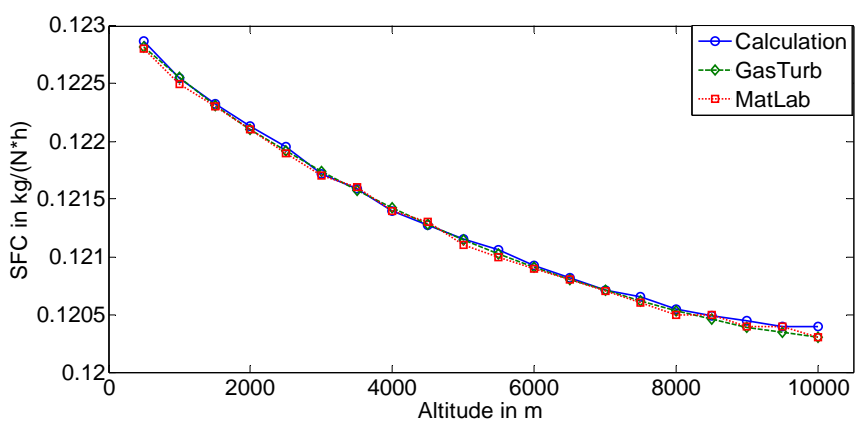

Figure 6: Variation of SFC with the altitude at a Mach number of 0.8

TABLE II: COMPARISON OF PARAMETERS

\begin{tabular}{|c|c|c|c|c|}
\hline \multirow{2}{*}{$\begin{array}{c}\text { Altitude } \\
(\mathbf{m})\end{array}$} & \multicolumn{4}{|c|}{ Analysis } \\
\cline { 2 - 5 } & Parameter & Calculation & MATLAB & GasTurb \\
\hline 10000 & Net Thrust $(\mathrm{kN})$ & 27.75 & 27.48 & 27.33 \\
\hline 500 & Net Thrust $(\mathrm{kN})$ & 63.38 & 63.19 & 63.01 \\
\hline 10000 & SFC $(\mathrm{kg} /(\mathrm{N} \cdot \mathrm{h}))$ & 0.1204 & 0.1203 & 0.1203 \\
\hline 500 & SFC $(\mathrm{kg} /(\mathrm{N} \cdot \mathrm{h}))$ & 0.1229 & 0.1228 & 0.1228 \\
\hline
\end{tabular}

The results achieved from the theoretical calculation and simulation at an altitude of $10000 \mathrm{~m}$ and $500 \mathrm{~m}$ can be seen in Table II. This information clearly shows the relationship between the altitude, specific fuel consumption and net thrust. 
The fuel/air ratio is the mass ratio of fuel to air present in a combustion process such as in an internal combustion engine. The relationship between fuel/air ratio and altitude is illustrated in Figure 7. Moreover, Figure 8 shows the relationship between the altitude and the mass flow rate of the working fluid. The mass flow rate decreases significantly as altitude increases.

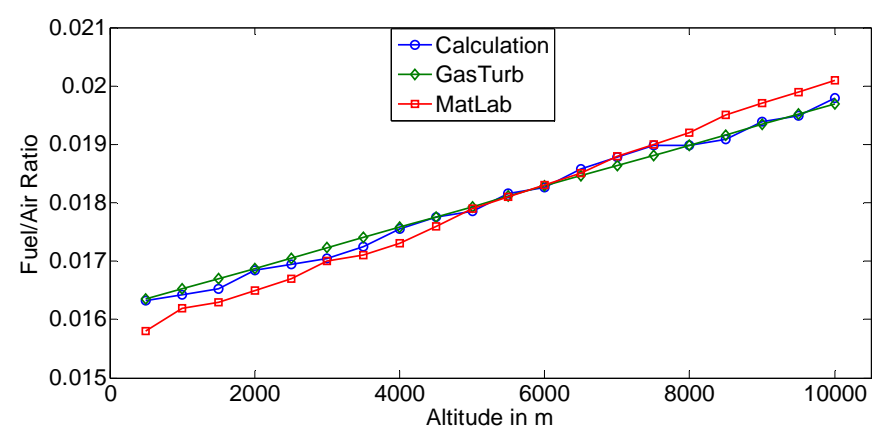

Figure 7: Relationship of fuel/air ratio and altitude at a Mach number of 0.8

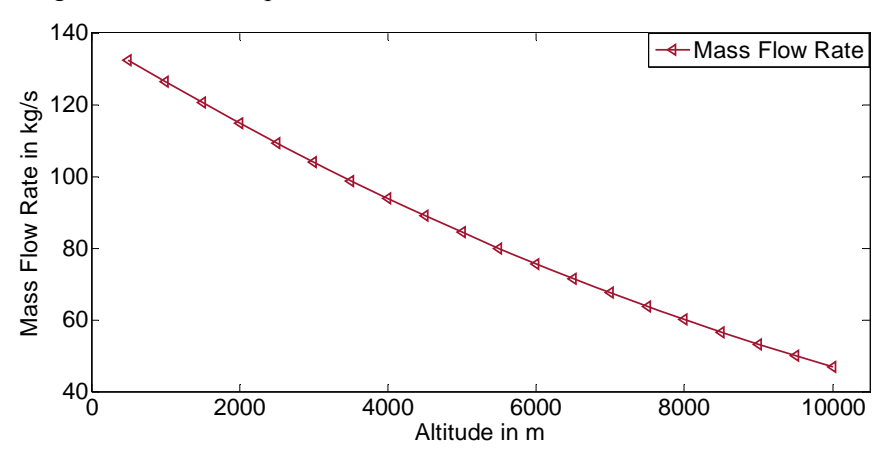

Figure 8: Relationship of mass flow rate and altitude at a Mach number of 0.8

A comparison of T-s Diagram and P-V Diagram (from GasTurb) at a flying altitude of $10000 \mathrm{~m}$ and $500 \mathrm{~m}$ are provided in Figures 9-12. As shown in Figures 10 and 12, a significant difference in pressure is visible at varying altitudes. The real gas turbine process differs from the theoretical Brayton cycle through the irreversibility of the technical state changes (1-2, 3-4). Nowadays the pressure changes due to heat losses in the combustion chamber can be minimized by appropriate measures (e.g., by using high temperature resistant ceramics). The actual Brayton cycle is an open cycle, since the heat is dissipated into the atmosphere.

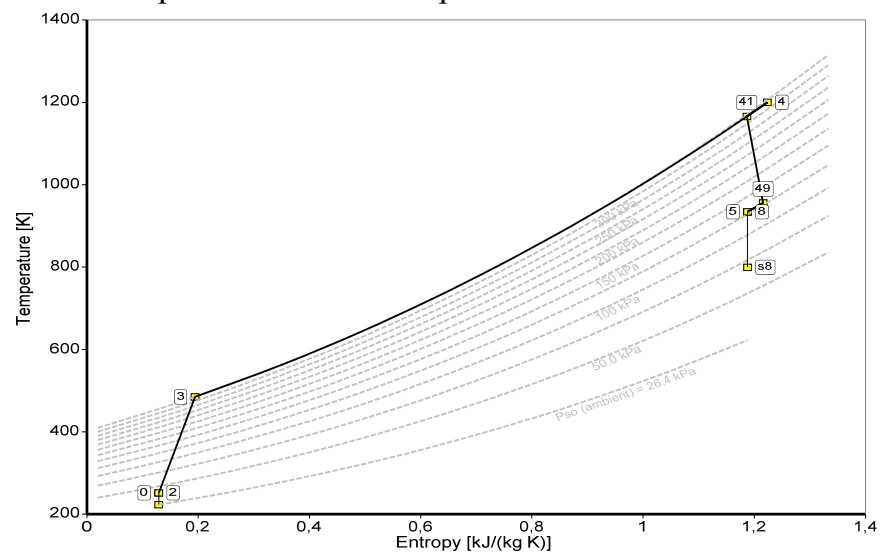

Figure 9: T-s Diagram at $10000 \mathrm{~m}$

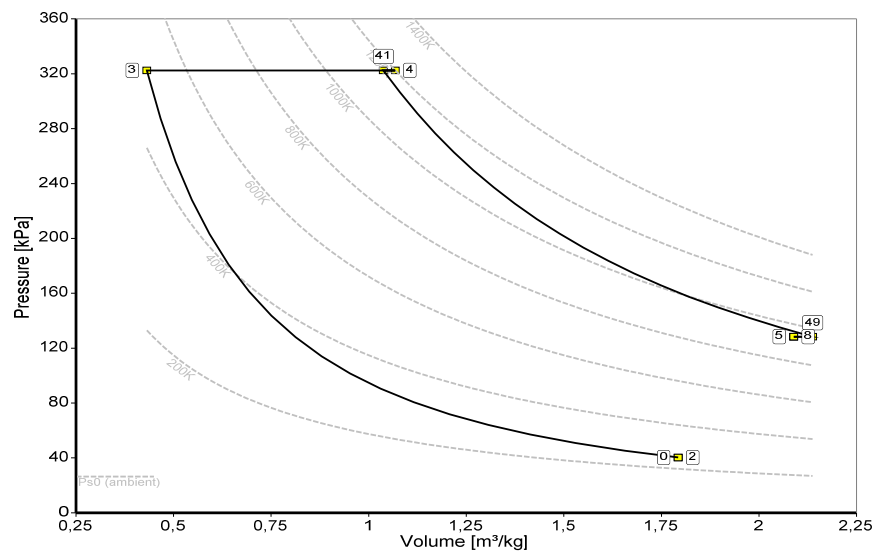

Figure 10: P-V Diagram at $10000 \mathrm{~m}$

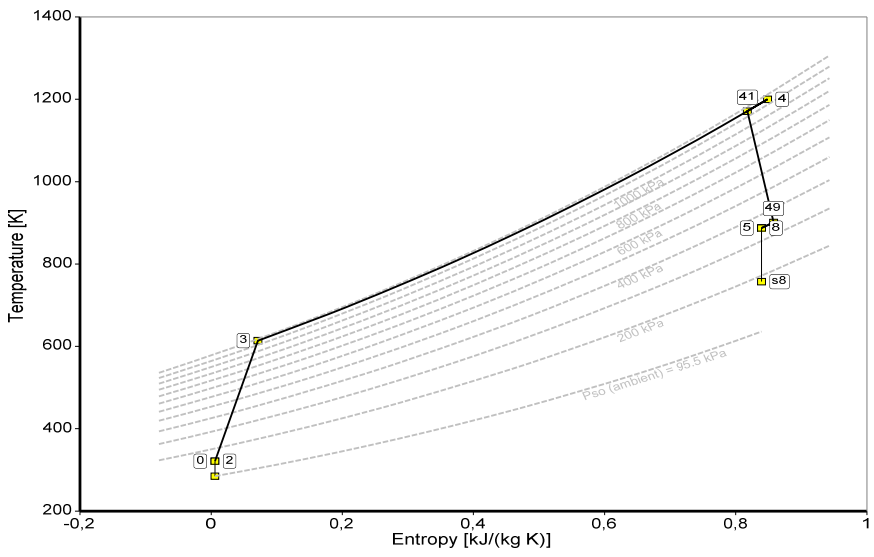

Figure 11: T-s Diagram at $500 \mathrm{~m}$

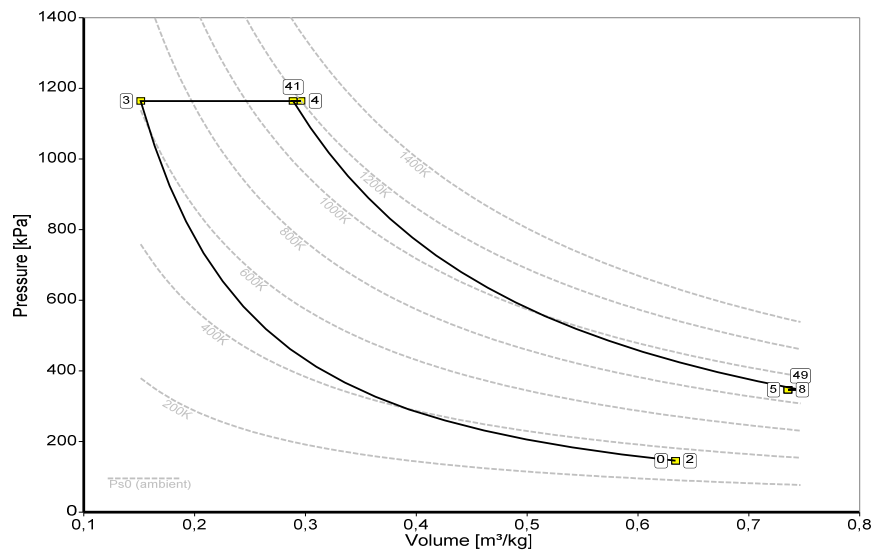

Figure 12: P-V Diagram at $500 \mathrm{~m}$

Today, a great attention has been paid on optimizing the fuel consumption, weight, size and usability while minimizing the noise level of gas turbine engines particularly which are used in aviation. However, additional equipment leading to an increase of weight may not be installed in improving the performance of these engines. One possible way to improve the efficiency is the increase of the turbine inlet temperatures. Currently temperatures close to $2000{ }^{\circ} \mathrm{C}$ are possible with the new material developments. Although this is a huge advantage which is leading to achieve higher combustion temperatures, it can cause to increase of nitrogen oxides in the combustion gases, which are responsible for the formation of ozone at 
ground level and smog. Another way to improve the efficiency of gas turbines is to design the components aerodynamically as possible with minimal losses. The advanced techniques based on computer aided design have been made this possible.

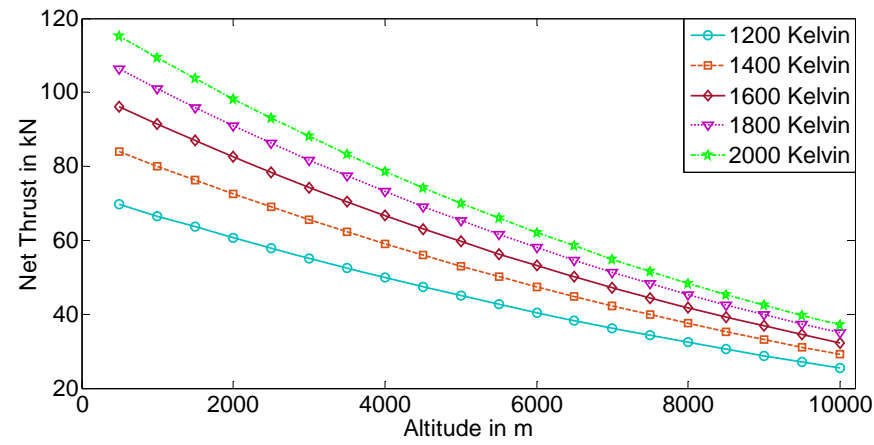

Figure 13: Variation of net thrust with the altitude and turbine inlet temperature at a Mach number of 0.8

Figure 13 illustrates the influence of the turbine inlet temperature on the net thrust, where the higher the turbine inlet temperature the higher the net thrust. As described above, the overall efficiency can be increased by increasing the turbine inlet temperature. Also, it should be noted that the increase of turbine inlet temperature should lead to an increase of the operating pressure ratio. Typically, thermal efficiency of gas turbines increase with the pressure ratio up to some level and then it starts to decrease. The maximum possible pressure ratio $\left(r_{p, \max }\right)$ can be presented as a function as a maximum and minimum temperatures $\left(T_{\max }\right.$ and $\left.T_{\min }\right)$ of the cycles as given in equation (28).

$$
r_{p}=\left(\frac{T_{\max }}{T_{\min }}\right)^{\left(\frac{\gamma}{2(\gamma-1)}\right)}
$$

Hence, an increase of the turbine inlet temperature should be performed with a greater care without losing the overall thermal efficiency.

Apart from the manual calculations, MATLAB model and GasTurb, the values shown in Table II were checked with an online calculator available for calculating single spool turbojet engines [11] and all of these values are in good agreement with the online results as well. This confirms the accuracy of the proposed models in this work.

\section{CONCLUSIONS}

In this work, a turbojet gas turbine engine was modelled theoretically and computationally. These models will help to study the performance of the turbojet engines at different operating conditions without performing heavily expensive experiments. The creation of such computer model can be the basis for the development of gas turbines and their digital control systems in the future. In addition, it was necessary to carry out a basic study on the functional sequence in a gas turbine engine which involves highly complex aerodynamic and thermodynamic processes. All of these actions were necessary to create a model as realistically as possible and with high precision. From the results, it can be seen that the error between the simulation and calculation is within $2 \%$ and this confirms the efficacy of the proposed models.

\section{REFERENCES}

[1] G. Jian-hua, and H. Ying-yun, "Modeling and Simulation of an Aero Turbojet Engine with GasTurb", 2011 International Conference on Intelligence Science and Information Engineering, pp.295-298, 2011.

[2] H. Rick, "Gasturbinen und Flugantriebe“, Springer Vieweg Verlag Berlin, 2013.

[3] P. W. Philip and F. Paul, "Gas Turbine Performance", $2^{\text {nd }}$ ed., Blackwell Science Ltd Oxford, 2004.

[4] National Aeronautics and Space Administration (2014) Gas Turbine Propulsion. Available from:

http://www.grc.nasa.gov/WWW/k-12/airplane/turbine.html

[Electronically accessed $11^{\text {th }}$ January 2015].

[5] T. James, "back to propellers", Engineering \& Technology, 4 (10), pp. 63-65, 2009.

[6] Flight Learnings (2011) Types of Turbine Engines. Available from http://www.flightlearnings.com/2010/03/06/types-of-turbine-engines/ [Electronically accessed $25^{\text {th }}$ January 2015].

[7] P. B. Meherwan, "Gas Turbine Engineering Handbook". Gulf Professional Publishing Houston, 2002.

[8] H. Cohen, GFC. Rogers, and HIH. Saravanamutto, "Gas Turbine Theory", $4^{\text {th }}$ ed., T.J. Press, Cornwall.

[9] The Engineering Toolbox (2014) International Standard Atmosphere. Available from:

http://www.engineeringtoolbox.com/international-standard-atmosphered_985.html

[Electronically accessed $26^{\text {th }}$ February 2014].

[10] GasTurb GmbH (2015) GasTurb 12. Available from: http://www.gasturb.de/index.html

[Electronically accessed $11^{\text {th }}$ January 2015].

[11] Thermodynamic (2000) Calculator for a turbojet engine with singel flow. Available from:

http://pages.infinit.net/nau/simple_flux_en.htm

[Electronically accessed $30^{\text {th }}$ January 2015].

[12] E. Benini, and S. Giacometti, "Design, manufacturing and operation of a small turbojet-engine for research purposes", Applied Energy, 84, pp. 1102-1116, 2007.

[13] M. Badami, P. Nuccio, and A. Signoretto, “ Experimental and numerical analysis of a small-scale turbojet engine", Energy Conversion and Management, 76, pp.225-233, 2013.

[14] O. Turan, "Exergetic effects of some design parameters on the small turbojet engine for unmanned air vehicle applications", Energy, 46, pp. 51-61, 2012.

[15] A. R. Tavakolpour-Saleh, S. A. R. Nasib, A. Sepasyan, and S. M. Hashemi, "Parametric and nonparametric system identification of an experimental turbojet engine", Aerospace Science and Technology, 43, pp. 21-29, 2015.

[16] S. Guo, F. Duan, H. Tang, S. Chuan Lim, and M. Sin Yip, “ Multiobjective optimization for centrifugal compressor of mini turbojet engine", Aerospace Science and Technology, 39, pp. 414-425, 2014.

[17] Y.A. Cengel, and M. Boles, "Thermodynamics: An Engineering Approach”, McGraw-Hill Bosten, 2010.

[18] D. G. Wilson, T. Korakianitis, "The Design of High-Efficiency Turbomachinery and Gas Turbines", The MIT Press United States of America, 2014.

[19] A. H. Lefebvre, and D. R. Ballal, "Gas Turbine Combustion", $2^{\text {nd }}$ ed., Taylor Francis; London, 1999.

[20] D. G. Wilson, and T. Korakianitis, "The design of high-efficiency turbomachinery and gas turbines", $2^{\text {nd }}$ ed., Prentice-Hall, Englewood Cliffs (NJ), 1998. 